\title{
Damage caused by Lophodermium needle cast in open-pollinated and control-crossed progeny trials of Scots pine (Pinus sylvestris L.)
}

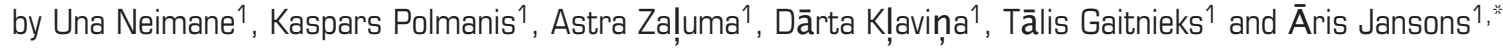

\begin{abstract}
The effect of genetics on the level of damage caused by Lophodermium needle cast to Scots pine was assessed in an openpollinated progeny trial (226 families from 12 provenances) and in a control-crossed progeny trial (72 families obtained by diallel crossing of 10 parent trees). Each of the trials was replicated on two test sites. The damage caused by the pathogen was estimated visually in June of the $2^{\text {nd }}$ and $6^{\text {th }}$ growing seasons using a five grade scale. Location and genetics were found to be significantly related to the level of needle cast damage. The proportion of severely damaged trees in each family correlated significantly between locations; moreover, the correlation was tighter for the control-crossed than open-pollinated families ( $r=0.59$ and $r=0.36$, respectively), indicating higher stability of resistance level against the disease for the genetically more homogeneous material. The effect of plus tree selection on the proportion of severely damaged trees was similar, regardless of its status (i.e., mother-tree or father-tree) in the family. The progenies of plus trees selected for resin production had the same level of damage by Lophodermium spp. needle cast as the selections made for growth and stem form.
\end{abstract}

Key words: Lophodermium spp., resistance breeding, provenances, tree improvement

\section{RÉSUMÉ}

Cette étude portait sur l'effet de la génétique sur le niveau de dégât lié au rouge cryptogamique des aiguilles de pin (Lophodermium) chez le pin sylvestre. Le dispositif comprenait un test de descendance à pollinisation naturelle sur 226 familles venant de 12 provenances, et un test de descendance avec pollinisation croisée sur 72 familles résultant des croisements diallèles sur 10 parents. Chacun des tests a été répété sur deux sites dessais. L'évaluation visuelle des dommages causés par l'agent pathogène sest faite aux mois de juin de la $2^{\mathrm{e}}$ et de la $6^{\mathrm{e}}$ année en utilisant une classification à cinq niveaux.

La localisation et la génétique étaient liées de façon significative au dégât provoqué par le rouge cryptogamique. La proportion des arbres très endommagés dans chaque famille était significativement corrélée entre les deux sites de tests; de plus, le niveau de corrélation était plus élevé chez les familles résultant de pollinisation croisée que chez celles obtenues par pollinisation libre ( $r=0,59$ et $r=0,36$, respectivement), ce qui laisse croire que la résistance à la maladie serait plus stable avec du matériel génétiquement plus homogène. L’effet lié à la sélection des arbres plus sur la proportion d’arbres très endommagés demeurait le même, peu importe son statut dans la famille (c. à d. arbre-mère ou arbre-père). Les descendances darbres plus choisis pour la production de résine montraient le même niveau de dommage par le rouge cryptogamique des aiguilles de pin (Lophodermium spp) que celles choisies pour la croissance et la forme de la tige.

Mots-clés : Lophodermium spp. croisements pour la résistance, provenances, amélioration génétique des arbres

\section{Introduction}

Scots pine (Pinus sylvestris L.) is a wide-spread and important species in the Baltic Sea region and therefore, extensive breeding is carried out in most of the countries of this area (Krakau et al. 2013). The targets for breeding include growth and stem quality and, in the northern parts of the region, survival, mostly linked to the development of frost hardiness (Berlin et al. 2009, 2010). Tree genetics is an important component in the resistance to diseases of numerous tree species and consequently has been incorporated in practical breeding (Carson and Carson 1989, Swedjemark et al. 2012, Bulman et al. 2013, Amerson et al. 2015). However, it has not been a part of the selection index for Scots pine in the breeding programs in this region and there are limited studies addressing genetic differences for Scots pine in relation to diseases (Stephan 1991, Krakau et al. 2013).
Recent studies have suggested that resistance may become an important component of breeding of Scots pine due to climatic changes. These changes may cause migration of pathogens and increase the incidence or the geographic distribution of diseases (La Porta et al. 2008). For instance, the northward spread and increasing infection rate of the well-known pathogen of pine, Diplodia sapinea (Fr.) Fuckel. (Diplodia tip blight) have lately been observed in the northern Baltic Sea region and this is at least partly linked to climatic factors (Adamson et al. 2015, Stenlid et al. 2017). Similarly, changes in climatic conditions have been suggested as a possible cause of the increased occurrence of blister rusts (Cronartium flaccidum (Alb. and Schwein) Winter and Peridermium pini (Willd. ex Pers.) Lév) in young Scots pine plantations in northern Sweden during the last decade. In the inventory of the progeny trials located in this region, a notable

\footnotetext{
${ }^{1}$ Latvian State Forest Research Institute "Silava”, Rigas 111, Salaspils, LV 2169, Latvia;

*Corresponding author e-mail: aris.jansons@silava.lv
} 
influence of genetics (similar differences between the families across the sites) on resistance has been found (Persson 2012).

Climatic changes have direct impacts not only to the pathogen but also to the trees due to increased abiotic stresses (La Porta et al. 2008). Insufficient fit to environmental conditions may increase the impact of these stresses and thus the risk of fungal infections (Karlman 2001, Bednářová et al. 2013). Therefore, the choice of provenance (genotypes) is important to ensure resistance of stands (Karlman 2001). Provenances transferred long distances are more susceptible to disease, presumably due to a combination of weakening by abiotic factors and lower tolerance to local strains of the fungus (Stephan and Liesebach 1996, Jansons and Baumanis 2005).

Lophodermium is a complex genus, consisting of both endophytes and pathogens of pines. Only Lophodermium seditiosum Minter, Staley \& Millar causes needle cast in natural stands (Bednáŕová et al. 2013). Lophodermium needle cast has been assessed in 44 Scots pine stands in Latvia where it was found present in $92 \%$ of cases. Thus it is both a common and economically important foliar pathogen of Scots pine in Latvia and Estonia (Jansons et al. 2008).

The occurrence of needle cast by Lophodermium spp. has been linked to climatic conditions (the amount of precipitation or the ratio of monthly precipitation to monthly mean air temperatures from May to August) that favour the pathogen (Stenström and Arvidsson 2001, Drenkhan 2011). Its impact may be increased by the influence of other (primary) pathogens such as the shoot and butt pathogen Gremmeniella abietina (Lagerberg) Morelet (Oliva et al. 2016). Needle cast affects pine seedlings in nurseries as well as in forest stands up to the age of 22-24 years (Hanso and Drenkhan 2012). In nurseries, fungicides are used to prevent infection of Lophodermium spp. and other species of needle casts (Kanaskie 1990). If not prevented in the nursery, infection continues to develop on the seedlings after planting (Klavina et al. 2012). However, there is a tendency to minimize the use of fungicides in the forest. Thus, the selection of resistant genetic material is necessary to improve the resistance of young stands (Baumanis et al. 1982, Stephan and Liesebach 1996). Tree breeding can work in line with the natural selection of individual trees that already occurs during the early stages of stand development (Hanso and Drenkhan 2007). Despite some earlier work, no Scots pine genotypes that are totally resistant to Lophodermium needle cast have been selected (Bednářová et al. 2013). The aim of this study was to assess the effect of genetics (provenance, family) on the level of damage caused by needle casts. The following hypotheses were tested: (1) provenances show higher resistance close to the location of their origin; (2) within the control-crossed families of the same plus tree, the extent of needle cast damage is significantly affected by gender of the parent-tree, i.e., if it is used as the female or male parent; and, (3) progenies of plus trees selected for resin production are less affected by the disease than progenies of plus trees selected for other traits.

\section{Materials and Methods}

The study sites were located in the Scots pine landscape beside at least one young stand to ensure the possibility of infestation by Lophodermium spp. The damage caused by needle cast and the survival of trees were assessed in two series of progeny trials (Fig. 1):
1) The open-pollinated progeny trial (226 families from 12 provenances) established on relatively fertile mineral soil (forest type Hylocomiosa, according to the classification of Bušs 1976), in the western and eastern regions of Latvia, near Tukums $\left(57^{\circ} 00^{\prime} \mathrm{N}, 23^{\circ} 10^{\prime} \mathrm{E}\right)$ and Kalsnava $\left(56^{\circ}\right.$ $\left.40^{\prime} \mathrm{N}, 25^{\circ} 58^{\prime} \mathrm{E}\right)$, respectively. Each family was represented by four trees in eight (Tukums) or two (Kalsnava) replications. Planting density was $2 \times 1 \mathrm{~m}$; one-year old seedlings were used. The mean number of trees in each family was 29 (Tukums) and 8 (Kalsnava); the mean number of families in each provenance was 19. For analysis, the provenances of the open-pollinated progeny trial were divided into six regions according to origin. The assessment was done during the second growing season.

2) The control-crossed progeny trial of 72 families (crosses of seven plus trees from Ugale $\left(57^{\circ} 15^{\prime} \mathrm{N}, 22^{\circ} 01^{\prime} \mathrm{E}\right)$ and three plus trees from Kalsnava) established on relatively poor, sandy soil (forest type Vacciniosa, according Bušs, 1976) in the central and eastern parts of Latvia, near Zvirgzde ( $56^{\circ} 41^{\prime} \mathrm{N}, 24^{\circ} 26^{\prime} \mathrm{E}$ ) and Kalsnava (56 $40^{\prime} \mathrm{N}$, $25^{\circ} 57^{\prime} \mathrm{E}$ ), respectively. Both trials were planted in four replicates of 15 trees, 2-year-old seedlings were used, and planting density was $2 \times 1 \mathrm{~m}$. The assessment was done during the sixth growing season. The mean number of trees in each family was 36.

Symptomatic Scots pine needles were sampled from 30 trees in each trial, and 20 needles from each tree collected. Samples were stored at $-20{ }^{\circ} \mathrm{C}$ until further processing. The presence of Lophodermium spp. was tested in the lab by observing the macroscopic features of the fungus (under a stereo microscope) and/or ten symptomatic needles were surface disinfected by submerging in 35\% hydrogen peroxide for 15-20 seconds and afterwards washed three times in sterile distilled water for one min. Fragments $0.5-1 \mathrm{~cm}$ of needles were subsequently placed on malt agar and incubated in the dark at $20^{\circ} \mathrm{C}$. Lophodermium spp. were identified according to morphological characteristics.

The damage caused by Lophodermium needle casts were assessed visually for all trees in June using a five-grade scale based on the proportion of damaged previous year needles (needles on one-year old shoots). Grade 1 corresponded to $0-5 \%$ of damaged needles, Grade 2 to $6-35 \%$, Grade 3 to $36-65 \%$, Grade 4 to $66-95 \%$ and Grade 5 (further referred also as severely damaged) to $96-100 \%$ of needles affected by the disease.

Distribution of individual tree damage grade was significantly different from normal distribution (results of Kolmogorov-Smirnov test); therefore, the non-parametric Chisquared test was used to assess the differences in the proportion of trees in each damage grade between the locations of each progeny trial, as well as between the provenances and provenance regions in both locations of the open-pollinated trial.

The proportion of severely damaged trees in each of the families was computed as a relation between number of trees assessed as Grade 5 (in Zvirgzde, the sum of Grade 5 and 4 was used) to the number of all trees in this family, and expressed as a percentage ( $\pm 95 \%$ confidence interval). For this parameter, the Kolmogorov-Smirnov test and Levene's test were used to check the conformity to the normal distribution and the homogeneity of variance, respectively. The 


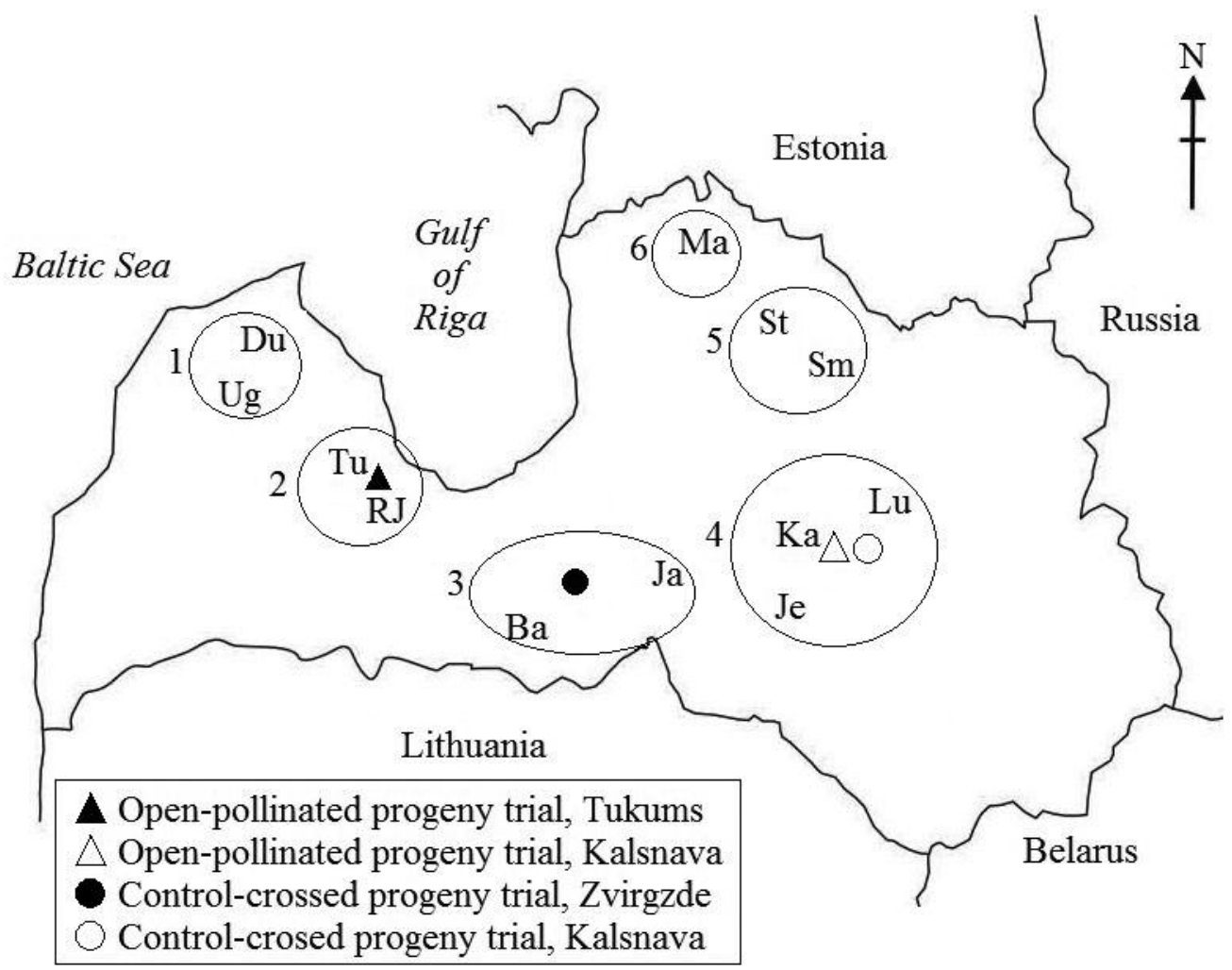

Fig. 1. Location of open-pollinated and control-crossed progeny trials and origin of their provenances: Du - Dundaga, Ug - Ugale, Tu -Tukums, RJ - Riga Jurmala, Ba - Bauska, Ja - Jaunjelgava, Je - Jekabpils, Ka - Kalsnava, Lu - Lubana, Ma - Mazsalaca, St Strenci and Sm - Smiltene) pooled into six regions according to their location of origin. The origin of the plus trees of the control crossed progeny trial: Ug - Ugale and Ka - Kalsnava.

proportion of severely damaged trees in a family met the assumptions of one-way analysis of variance (ANOVA). The ANOVA was used to assess the differences of the proportion of severely damaged trees in the family between the locations of each progeny trial, and between the provenances (and the provenance regions) in both locations of the open-pollinated progeny trial. The two-way analysis of variance was used to assess the effect of genotype - site interaction on the damage in the open-pollinated progeny trial. The Pearson correlation test assessed the relations of the proportion of the severely damaged trees in the families between the locations of each progeny trial, as well as the relations between the mean proportion of severely damaged trees in families of each provenance and the distance between the origin of the provenance and the test site.

To test the effect of gender of the plus tree in crossing, each was compared according to its status (i.e., mother-tree or father-tree) in the family. The t-test was used to assess the differences of the proportion of damaged trees between the families of the same plus tree used as the mother-tree and as the fathertree in both locations of the control-crossed progeny trial.

Similarly, in the open- pollinated progeny trial, the proportion of the most damaged trees in the family was estimated by $\mathrm{t}$-test to determine differences between plus trees selected for resin production and those selected for growth and stem quality, being represented by 21 families and by 12 (Kalsnava) to 14 (Tukums) families, respectively.

\section{Results}

Open-pollinated progeny trials in Kalsnava and Tukums had similar rates of survival: $78 \%$ (67\% to $88 \%$ among the provenances) and $72 \%$ (66\% to $81 \%$ ), respectively. In the controlcrossed progeny trial, survival exceeded $80 \%$ (from $41 \%$ to $100 \%$ between families, only one $<50 \%)$ and $83 \%(50 \%$ to $81 \%$ ) in Kalsnava and Zvirgzde, respectively.

The location of the trial had a significant effect on the level of damage. The distribution of trees among the grades of damage differed significantly ( $\chi^{2}$ test, $p<0.001$ ) between the locations in both types of progeny trials (Fig. 2). Significant (ANOVA, $p<0.001$ ) differences between the proportion of the severely (i.e., Grade 5) damaged trees and the locations of each progeny trial were found. In the open-pollinated progeny trial, the proportion of severely damaged trees was $47 \%$ (Kalsnava) and $60 \%$ (Tukums), while in the control-crossed progeny trial $8 \%$ (Kalsnava) and $51 \%$ (Zvirgzde) were observed. The proportion of trees with no more than 35\% damaged needles (Grade 1 and 2) was considerably higher in the controlcrossed progeny trial in Kalsnava (26\%) in comparison to all other sites where this proportion did not exceed $7 \%$.

Both types of progeny trials showed that the level of damage by needle cast was affected by host genetics. In both Tukums and Kalsnava of the open-pollinated progeny trial, the distribution of trees among the grades of damage differed significantly among the provenances $\left(\chi^{2}\right.$ test, $p<0.001$ and $p=0.001)$, and among the provenances ( $\chi^{2}$ test, $p<0.001$ and 


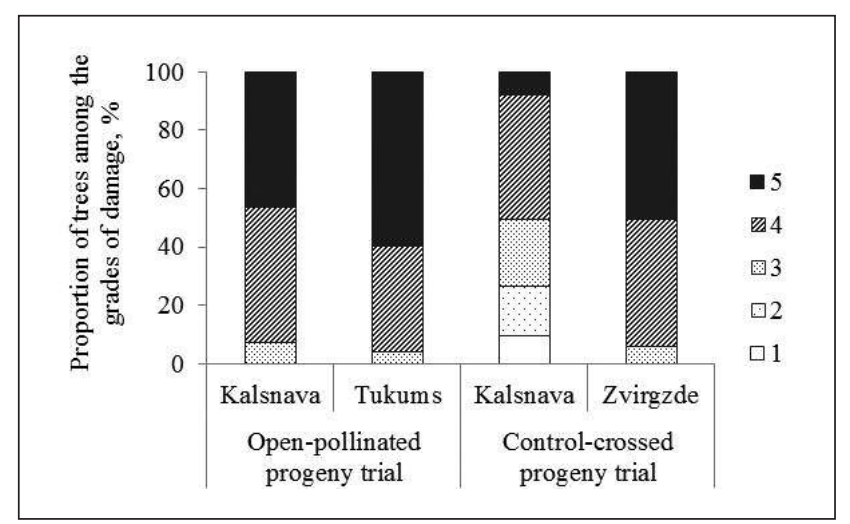

Fig. 2. Distribution of trees among grades 1 to 5 of the damage caused by needle cast $p=0.028$ in Tukums and regions of Kalsnava, respectively). Similarly, analysis of a single trial (Tukums) revealed significant (ANOVA, $p<0.001)$ differences in the proportion of the severely damaged trees in the family between the provenances (Fig. 3) and between the regions of provenances (Fig. 4). These differences were mainly caused by the superior vitality (low proportion of damaged trees) to needle cast of the progenies from the Dundaga provenance. Among the families of this provenance, the proportion of severely damaged trees did not exceed 55\%, while the most damaged family in each of the other provenances reached $76-100 \%$. In contrast, in the other open-pollinated trial (Kalsnava), the proportion of severely damaged trees in the families did not differ significantly among the provenances $(p=0.180)$ and among the regions of the provenances $(p=0.245)$.

The relation between the provenance mean proportion of severely damaged trees in families and the transfer distance (i.e., the distance of provenance origin to test site) was not significant $(p=0.662)$. Thus no geographic pattern of resistance was found (Fig. 5). For instance, the provenance of Tukums had one of the highest levels of resistance (lowest mean proportion of severely damaged trees in the family) in Kalsnava (174 km from the origin site), but in Tukums (place of origin) it had a medium ranking. Similarly, the provenance of Kalsnava had good resistance in Tukums (175 km from the origin site), while it was the second worst in Kalsnava (place of origin). However, the provenance of Dundaga showed a higher resistance in Tukums, i.e., close to the place of origin $(77 \mathrm{~km})$, than in the farther located Kalsnava $(237 \mathrm{~km})$. Hence, there was a significant genotype - site interaction effect (i.e., trial location $x$ provenance and trial location $x$ family) on the needle cast damage $(p<0.05)$.

Significant $(p<0.001)$ relations of the proportion of severely damaged trees in the family between locations of each trial were found. The Pearson's correlation coefficient between Tukums and Kalsnava (open-pollinated trial) was $r=0.36$, while between Zvirgzde and Kalsnava (control-crossed trial) $r=0.59$. Part of the families showed similar levels of damage in each of the compared locations. For instance, open-pollinated families from Tukums, Dundaga, Ugale and Lubana provenances had relatively low damage, while families from Jaunjelgava, Jekabpils and Bauska provenances had a relatively high proportion of trees that were severely damaged by needle cast in both locations (Kalsnava and Tukums). In contrast, several provenances (for instance, Strenci) had considerable differences in the proportion of damaged trees between locations. 


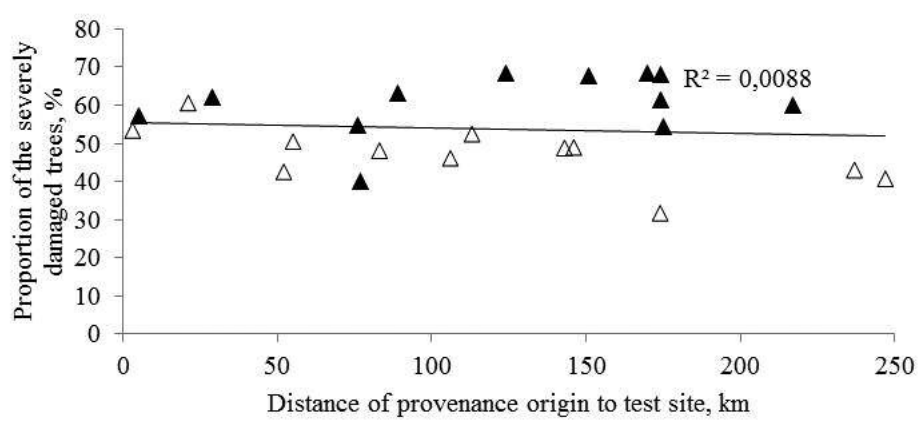

Fig. 5. Relationship between provenance mean proportion of severely damaged trees (grade 5) in families and the distance of provenance origin to test site in Tukums (black triangles) and Kalsnava (white triangles)

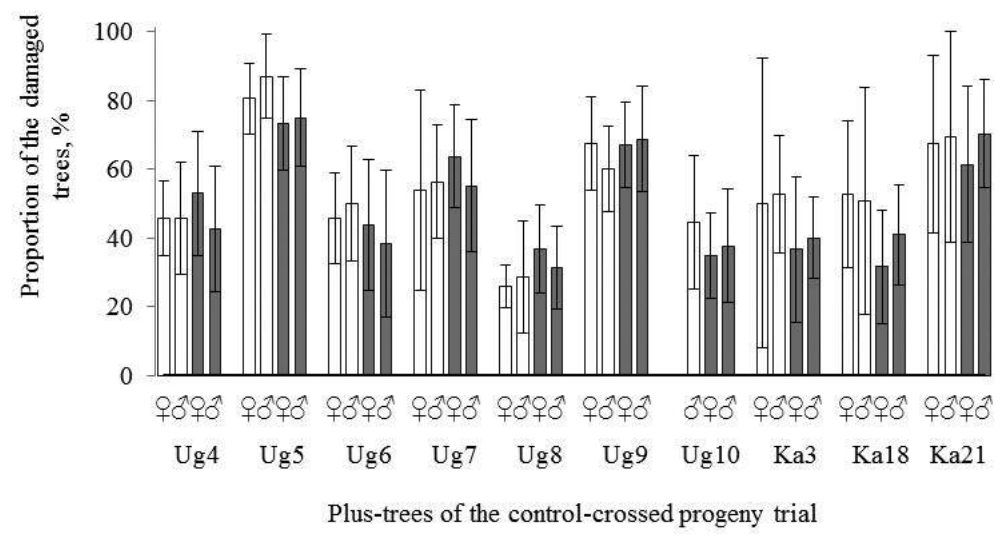

Fig. 6. The proportion of damaged (Grade 5 in Zvirgzde, sum of Grade 5 and 4 in Kalsnava) trees of the progenies ( \pm confidence interval) of plus trees used as the mother tree ( ) and as the father tree ( ) in Zvirgzde (white bars) and Kalsnava (grey bars)

In the control-crossed progeny trial, progenies of the same plus tree showed a similar $(p>0.05)$ proportion of damaged trees in each family, regardless if the mother-tree or the father-tree and the location of the trial (Fig. 6). Moreover, significant differences were found between families of the different parent trees. For instance, progenies of the plus tree Ug8 had significantly $(p<0.05)$ superior vitality (low proportion of severely damaged trees) in comparison to the progenies of the plus tree Ug5.

Needle cast damage was compared between families of two types of plus trees from a single provenance: those selected for growth and stem quality and those selected for superior resin production. Families of both types showed a similar distribution of trees in different needle cast damage grades ( $x 2$ test, $p=0.783$ and $p=0.182$ in Kalsnava and Tukums, respectively), as well as similar proportions of severely damaged trees (ANOVA, $p=0.719$ and $p=0.742$ in Kalsnava and Tukums, respectively). The proportions of the severely damaged progenies of the plus trees selected for growth and stem quality and for resin production was $47 \%$ and $50 \%$ in Kalsnava and $69 \%$ and $67 \%$ in Tukums, respectively.

\section{Discussion and Conclusions}

The significant effect of location on the level of damage by needle cast (Fig. 2) is in line with previous findings in southern and central Sweden (Martinsson 1979). In both types of progeny trials, less damage was found in Kalsnava, eastern Latvia. Kalsnava and the other sites of the progeny trials (Tukums and Zvirgzde) are separated by Europe's submeridional physiogeographic axis. This axis divides the region based on the dominance of oceanic and continental air masses (Krauklis and Zarina 2002). Thus, there are climatic differences across the WestEast gradient in Latvia (Krauklis and Zariña 2002, Draveniece 2007).

Differences in soil fertility could also affect the incidence of needle cast as this disease is more frequent in stands on sandy soils (Kuzmina and Kuzmin 2008). In our study, similar soil conditions between the trials within an experimental series (open-pollinated and controlcrossed) were used. Age of seedlings affects the impact of the disease: younger, smaller seedlings have lower nutrient reserves and total needle mass, therefore their growth and survival is more affected by needle cast (Kurkela et al. 2009). Infection (occurrence) of needle cast is to some extent affected by distance from the canopy to the forest floor (Millberg 2015) as can also be seen in our results. In general, the occurrence of needle cast decreases after saplings reach 10 years and host age limit is $22-24$ years (Drenkhan 2011, Hanso and Drenkhan 2012). However, a proportion of the severely damaged trees was higher in the open-pollinated progeny trial in comparison to the controlcrossing progeny trial, which were four years younger and originated from trees from different provenances.

The level of needle cast damage was significantly affected by host genetics (Fig. 3, 4, 6). This is in line with other studies where notable differences between plus tree progenies (Squillace et al. 1975) and provenances (Martinsson 1979, Ostry and Nicholls 1989, Jansons et al. 2008) were found. Differences in the amplitude of proportion of severely damaged trees in families between the trials may be caused by the overall level of disease: a larger difference in less damaged trials had been reported in the analysis of needle cast (Pìrāgs et al. 1990); in contrast, a higher difference between families in more damaged trials (in comparison to less damaged) has been found in Scleroderris pine canker (Gremmeniella abietina) in Sweden (Eriksson 2008). The impact of genetic differences of the host on the level of damage in our study was 
evaluated only during a single growing season. However, the severity of the disease can notably increase, affecting survival of trees in the case of repeated pathogen attack or abiotic stress and may thus affect the magnitude of genetic differences (Oliva et al. 2016).

The stability of the level of damage in different locations is in accordance with the high stability of other traits analysed in Scots pine progeny trials under different climatic $(r=0.69)$ and edaphic ( $r=0.60-0.80)$ conditions (Baumanis et al. 1989). Moreover, the family mean correlation between locations was tighter for control-crossed families in comparison to openpollinated families, indicating the influence of genetics on the level of damage caused by this disease that was more pronounced in more genetically homogenous material (among sibs in contrast to among half-sibs).

Some studies have noted differences in fungi-tree interactions linked to maternal or paternal effects of the host. For example, genetic variation in the length of lesions in the inner bark after artificial inoculations of Heterobasidion in 48 fullsib families from controlled crosses between 16 grafted clones (using eight clones as mothers and eight as fathers) were tested and a high correlation was found between the $H$. parviporum lesion lengths of Norway spruce male parents and offspring but not for the female parents and offspring (Skrøppa et al. 2015). However, such cases are rare and in our study no specific maternal or paternal genetic effects on the level of needle cast damages was detected (Fig. 6). This is in accordance with other studies analysing parental effects for other traits in trials of controlled crosses e.g., for stem quality of Scots pine (Giertych 1991).

Monoterpenes and diterpenoid resin acids are the main components of oleoresin. Genetic variations in these components have been reported for conifers (Bridgen and Hanover 1982). The role of terpenoids, including resin acids, in conifer defence against bark beetle-associated fungi, larvae of European sawfly (feeding on one-year old foliage) and root rotcausing fungi has been proven in other studies (Rishbeth 1972, Villari et al. 2012). The concentration of resin acids in oleoresin varied greatly (from $9 \%$ to $54 \%$ ) between provenances (Bridgen and Hanover 1982); however, no linkage between resin acid concentration and total resin production has been noted. Presumably it could be why observed progenies of pines with intensive resin production were not significantly less affected by needle cast compared to progenies of other pines from the same provenance in our study.

There was a significant effect of location and genetics on the level of needle cast damage to Scots pine seedlings. Both in open-pollinated and control-crossed progeny trials, the proportion of severely damaged trees was significantly lower in Kalsnava, i.e., in the eastern, more continental part of Latvia. The proportion of severely damaged trees in a family correlated significantly between the locations. This was stronger for the control-crossed progeny, indicating higher stability of the more homogeneous genetic material in different ecological backgrounds. All of our hypothesis were rejected.

The proportion of severely damaged trees differed between provenances, but the differences were not associated with distance from the location of the provenances origin to the location of the study site. Genotype x environment interaction could play an important role in resistance, and thus needs to be considered and assessed in tree breeding (Li et al. 2017); however, with the material included in the study it was not possible to draw any firm conclusions. The effect of the plus tree was also similar, regardless of status (i.e., mother-tree or father-tree) in the family. Moreover, the progenies of plus trees selected for growth and stem quality were similarly affected by the disease, compared to progenies of plus trees selected for resin production.

\section{Acknowledgement}

This study was carried out under the project "Forest tree breeding for establishment of high genetic quality stands". The authors acknowledge Silva Senhofa for useful discussion to improve earlier drafts of the manuscript.

\section{References}

Adamson, K., D. Klavina, R. Drenkhan, T. Gaitnieks and M. Hanso. 2015. Diplodia sapinea is colonizing the native Scots pine (Pinus sylvestris) in the northern Baltics. European Journal of Plant Pathology 143(2): 343-350. doi:10.1007/s10658-015-0686-8.

Amerson, H.V., C.D. Nelson, T.L. Kubisiak, E.G. Kuhlman and S. Garcia. 2015. Identification of nine pathotype-specific genes conferring resistance to fusiform rust in loblolly pine (Pinus taeda L.). Forests 6(8): 2739-2761. doi:10.3390/f6082739.

Baumanis, I., D. Pīrāgs and Z. Spalvinšs. 1982. Resistance trials of Scots pine clones in Latvian SSR. In H.M. Heybroek, B.R. Stephan and K. von Weissenberg. Proceedings of the Third International Workshop on the Genetics of Host-Parasite Interactions in Forestry: Resistance to Diseases and Pests in Forest Trees, Wageningen, The Netherlands, 14-21 September 1980. pp. 448-449. PUDOC, Centre for Agricultural Publishing and Documentation, Wageningen, The Netherlands.

Baumanis, I., J. Birğelis and D. Pīrāgs. 1989. Needlecast resistance of different Scots pine provenances. In Protection of pine and fir in the Latvian SSR. pp. 111-118. Zinatne, Riga, Latvia. [Translated from Russian].

Bednářová, M., M. Dvořák, J. Janoušek and L. Jankovský. 2013. Other foliar diseases of coniferous trees. In P. Gonthier and G. Nicolotti (eds.). Infectious Forest Diseases. pp. 458-487. Wallingford: CABI. doi:10.1079/9781780640402.0000.

Berlin, M., Ö. Danell, G. Jansson, B. Andersson, B. Elfving and T. Ericsson. 2009. A model to estimate economic weight of tree survival relative to volume production taking patchiness into account. Scandinavian Journal of Forestry Research 24(4): 278-287. doi:10.1080/02827580903117388.

Berlin, M., Lönnstedt, L., Jansson, G., Danell, Ö. and Ericsson, T. 2010. Developing a Scots pine breeding objective: A case study involving a Swedish sawmill. Silva Fennica 44(4): 643-656. doi:10.14214/sf.132.

Bridgen, M.R. and Hanover J.W. 1982. Indirect selection for pest resistance using terpenoid compounds. In Proceedings of The Third International Workshop on the Genetics of Host-Parasite Interactions in Forestry, Wageningen, the Netherlands, 14-21 September, 1980. pp. 161-168. Centre for Agricultural Publishing and Documentation, Wageningen, the Netherlands.

Bulman, L.S., M.A. Dick, R.J. Ganley, R.L. McDougal, A. Schwelm and R. E. Bradshaw. 2013. Dothistroma needle blight. In P. Gonthier and G. Nicolotti (eds.). Infectious Forest Diseases. pp. 436-457. Wallingford: CABI. doi:10.1079/9781780640402.0000.

Bušs, K. 1976. Basis of Forest classification in Latvia SSR. LRZTIPI, Riga. [Translated from Latvian].

Carson, S.D. and M.J. Carson. 1989. Breeding for resistance in forest trees - A quantitative genetic approach. Annual Review of Phytopathology 27: 373-395. doi:10.1146/annurev.py.27.090189.002105. Draveniece, A. 2007. Oceanic and continental air masses in Latvia. University of Latvia, Institute of Biology, Latvijas Vegetācija No.14. 
Drenkhan, R. 2011. Epidemiological investigation of pine foliage diseases by the use of the needle trace method. Doctoral thesis, Estonian University of Life Sciences, Tartu, Estonia.

Eriksson, G. 2008. Pinus sylvestris: Recent Genetic Research. Department of Plant Biology and Forest Genetics, Genetic Center, Swedish University of Agricultural Sciences, Uppsala, Sweden, pp. 115.

Giertych, M. 1991. Inheritance of tree form. In M. Giertych and Cs. Mátyás (eds.). Genetics of Scots pine. pp. 243-254. Elsevier Science Publishers, Amsterdam, The Netherlands.

Hanso, M. and R. Drenkhan. 2007. Retrospective analysis of Lophodermium seditiosum epidemics in Estonia. Acta Silvatica and Lignaria Hungarica, Special Edition: 31-45.

Hanso, M. and R. Drenkhan. 2012. Lophodermium needle cast, insect defoliation and growth responses of young Scots pines in Estonia. Forest Pathology 42(2): 124-135. doi: 10.1111/j.14390329.2011.00728.x.

Jansons, $\bar{A}$. and I. Baumanis. 2005. Growth dynamics of Scots pine geographical provenances in Latvia. Baltic Forestry 11(2): 29-37.

Jansons, $\bar{A}$., U. Neimane and I. Baumanis. 2008. Needlecast resistance of Scots pine and possibilities of its improvement. Mežzinātne 18: 3-18. [Translated from Latvian].

Kanaskie, A. 1990. Lophodermium needle cast of Scotch pine. In P.B. Hamm, S.J. Campbell and E.M. Hansen (eds.). Growing healthy seedlings: Identification and management of pests in northwest forest nurseries. p. 34. Oregon State University, Oregon, USA.

Karlman, M. 2001. Risks associated with the introduction of Pinus contorta in northern Sweden with respect to pathogens. Forest Ecology and Management 141: 97-105. doi:10.1016/S0378-1127(00)00492-8. Kḷaviņa, D., R.D. Kiesnere, A.M. Korica, N. Arhipova, M. Daugavietis and T. Gaitnieks. 2012. Evaluation of impact of pine bark extracts on mycelial growth of Lophodermium seditiosum in vitro. Mežzinātne 26(59): 167-181. [Translated from Latvian].

Krakau, U.K., M. Liesebach, T. Aronen, M.A. Lelu-Walter and V. Schneck. 2013. Scots pine (Pinus sylvestris L.). In L.E. Pâques (ed.). Forest tree breeding in Europe: Current state-of-the-art and perspectives. pp. 267-323. Springer, London. doi:10.1007/978-94-007-6146-9. Krauklis, Ā. and A. Zarina. 2002. European hornbeam in the landscape of its northern distribution limit in Latvia. Folia Geographica 10: 16-47. [Translated from Latvian].

Kurkela, T., R. Drenkhan, M. Vuorinen and M. Hanso. 2009. Growth response of young Scots pines to needle loss assessed from productive foliage. Forestry Studies 50: 5-22. doi: 10.2478/v10132011-0066-x.

Kuzmina, N. and S. Kuzmin. 2008. Intraspecific response of Scots pine (Pinus sylvestris L.) to pathogens in a provenance trial in Middle Siberia. Eurasian Journal of Forest Research 11(2): 51-59.

La Porta, N., P. Capretti, I.M. Thomsen, R. Kasanen, A.M. Hietala and K. Von Weissenberg. 2008. Forest pathogens with higher damage potential due to climate change in Europe. Canadian Journal of Plant Pathology 30(2): 177-195. doi:10.1080/07060661.2008.10540534. Li, Y., Suontama, M., Burdon, R.D. and Dungey, H.S. 2017. Genotype by environment interactions in forest tree breeding: review of methodology and perspectives on research and application. Tree Genetics \& Genomes (2017) 13: 60. doi:10.1007/s11295-017-1144-X Martinsson, O. 1979. Testing Scots pine for resistance to Lophodermium needle cast. Studia Forestalia Suecica 150.

Millberg, H. 2015. Foliar fungi of Scots pine (Pinus sylvestris). Doctoral thesis, Swedish University of Agricultural Sciences, Uppsala, Sweden.
Oliva J., J. Stenlid, L. Grönkvist-Wichmann, K. Wahlström, M. Jonsson, I. Drobyshev and E. Stenström. 2016. Pathogen-induced defoliation of Pinus sylvestris leads to tree decline and death from secondary biotic factors. Forest Ecology and Management 379: 273-280. doi:10.1016/j.foreco.2016.08.011

Ostry, M.E. and T.H. Nicholls. 1989. Effect of Lophodermium seditiosum on growth of pine nursery seedlings in Wisconsin. Plant Disease 73(10): 798-800. doi:10.1094/PD-73-0798.

Persson, T. 2012. Genotype by environment interaction for survival, growth and Cronartium resistance in northern Scots pine. In Proceedings of International Conference: Genetic Aspects of Adaptation and Mitigation: Forest Health, Wood Quality and Biomass Production, Riga, Latvia, 3-5 October, 2012. p. 150. LSFRI Silava, Salaspils, Latvia.

Pīrāgs, D., I. Baumanis and J. Smilga. 1990. The dynamics of forest tree breeding. In The role of tree breeding in the improvement of Latvian forests. pp. 3-11. Zinatne, Riga, Latvia. [Translated from Russian].

Rishbeth, J. 1972. A discussion on disease resistance in plants Resistance to fungal pathogens of tree roots. In Proceedings of the Royal Society of London, Series V, Biological sciences 181: 333-351. doi:10.1098/rspb.1972.0054.

Skrøppa, T., H. Solheim and A. Steffenrem. 2015. Genetic variation, inheritance patterns and parent-offspring relationships after artificial inoculations with Heterobasidion parviporum and Ceratocystis polonica in Norway spruce seed orchards and progeny tests. Silva Fennica 49: 12 p. doi:10.14214/sf.1191.

Squillace, A.E., J.G.A. La Bastide and C.L.H. Van Vredenburch. 1975. Genetic variation and breeding of Scots pine in the Netherlands. Forest Science 21(4): 341-352.

Stenlid, J., J. Oliva and J. Boberg. 2017. Climatic influence on recent outbreaks of Dothistroma septosporum and other needle diseases of pine in Sweden. Abstract Book: IUFRO 125 th Anniversary Congress, Freiburg, Germany, 18-22 September 2017. p. 210.

Stenström, E. and B. Arvidsson. 2001. Fungicidal control of Lophodermium seditiosum on Pinus sylvestris seedlings in Swedish forest nurseries. Scandinavian Journal of Forest Research 16(2): 147-154. doi:10.1080/028275801300088224.

Stephan, B.R. 1991. Inheritance of resistance to biotic factors. In M. Giertych and Cs. Mátyás (eds.). Genetics of Scots pine. pp. 205-217. Elsevier Science Publishers, Amsterdam, The Netherlands.

Stephan, B.R. and M. Liesebach. 1996. Results of the IUFRO 1982 Scots pine (Pinus sylvestris L.) provenance experiment in southwestern Germany. Silvae Genetica 45(5): 342-349.

Swedjemark, G., A.K. Borg-Karlson and B. Karlsson. 2012. Breeding for resistance in Norway spruce to the root and butt rot fungi Heterobasidion spp. In R.A. Sniezko, A.D. Yanchuk, J.T. Kliejunas, K.M. Palmieri, J.M. Alexander and S.J. Frankel (eds.). Proceedings of the $4^{\text {th }}$ International Workshop on Genetics of Host-Parasite Interactions in Forestry. General Technical Report PSW-GTR-240. pp. 162-166. USDA Forest Service, Albany, CA.

Villari, C., A. Battisti, S. Chakraborty, M. Michelozzi, P. Bonello and M. Faccoli. 2012. Nutritional and pathogenic fungi associated with the pine engraver beetle trigger comparable defenses in Scots pine. Tree Physiology 32(7): 867-879. doi:10.1093/treephys/tps056.

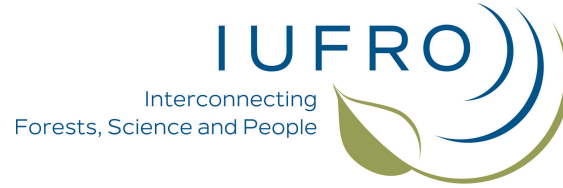

This paper is based on material that was presented at the meeting of IUFRO Working Party 7.02.02 - Foliage, Shoot and Stem Diseases, May 7-11, 2017, Niagara Falls, Ontario, Canada 